\title{
THE IMPACT OF CREDIT UNIONS ON THE RATES OFFERED FOR RETAIL DEPOSITS BY BANKS AND THRIFT INSTITUTIONS
}

September 10, 2002

Timothy H. Hannan*

Stop 149

Federal Reserve Baord

Washington DC 20551

Phone: 202-452-2919

Fax: 202-728-5838

email: thannan@frb.gov

*Senior Economist, Board of Governors of the Federal Reserve System.

The views expressed herein are those of the author and do not necessarily reflect the views of the Board of Governors of the Federal Reserve System or its staff. The author would like to thank Dean Amel, Robert Feinberg, and Robin Prager for helpful comments and Eli Mou for research assistance. 


\begin{abstract}
Because of the increasing significance of credit unions as potential competitors for consumer deposits, this paper examines the impact of the market presence of credit unions, variously measured, on the rates for three different types of consumer deposits offered by banks and thrift institutions. In contrast to previous studies, the sample employed covers the nation as a whole, incorporates all large urban areas, and employs survey data on deposit rates for a substantially larger number of institutions than previously employed. Despite circumstance that are argued to militate against the finding of a relationship, regression analyses yield positive coefficients of the measures of credit union presence, with statistical significance in a number of cases.
\end{abstract}

Key Words: Credit Unions, Competition, Deposit Rates 


\section{THE IMPACT OF CREDIT UNIONS ON THE RATES OFFERED FOR RETAIL DEPOSITS BY BANKS AND THRIFT INSTITUTIONS}

\section{Introduction.}

By some measures, credit unions have become increasingly important players in the market for consumer deposits. While only about one percent of the adult population belonged to credit unions in $1935,{ }^{1}$ by year end 1996 there were about 11,400 credit unions in existence, serving an estimated 70 million individual members, or about 34 percent of the population over 16 years of age. ${ }^{2}$ In the decade previous to 1996 alone, credit union membership grew by nearly 40 percent. $^{3}$

Another sign of the growing importance of credit unions may be seen in recent legal and legislative battles on the issue of who is eligible to become a member of a credit union. By law, credit union members must be united by a "common bond of occupation or association, or belong to groups within a well-defined neighborhood, community, or rural district." (Federal Credit Union Act of 1934). In a 1998 Supreme Court case pitting commercial banks against credit unions, the Court found in favor of banks, ruling that newly chartered credit unions may not combine multiple common bonds within a single institution. A few months later, however, Congress passed into law legislation that essentially reversed the Supreme Court's ruling.

Measured in terms of assets, however, credit unions do not look so imposing. Credit union assets came to only $\$ 327$ billion in 1996, or about 6 percent of the assets of commercial banks and thrift institutions. ${ }^{4}$ This stark difference between the proportion of the adult population counted as members of credit unions (34 percent) and the proportion of assets held by them (6 percent) clearly reflects the fact that many members hold small or negligible deposit balances in their credit unions.

\footnotetext{
${ }^{1}$ American Bankers Association,189, p. 29.

${ }^{2}$ US Treasury, 1997, p.15.

${ }^{3}$ US Treasury, 1997, p.23.

${ }^{4}$ US Treasury, 1997, p.15.
} 
The issue of the impact of credit unions in deposit markets is clearly relevant to antitrust assessments of the competitive harm that might stem from a proposed merger and acquisition in the banking industry. The reason is that a proposed merger or acquisition may be less likely to impose a substantial competitive harm if credit unions represent a substantial competitive force in the market at issue. ${ }^{5}$

In this paper, I seek to assess the competitive impact of credit unions by examining the deposit pricing behavior of banks and thrift institutions in markets in which credit unions operate. The data employed focus on a large number of metropolitan markets, and, unlike most previous studies, data on the importance of credit unions in each market will be adjusted to account for the fact that many large credit unions operate in numerous local areas and, in some cases, more than one state. Also addressed will be the distinction between occupational and community credit unions, which can differ substantially in terms of the customer base that they can serve.

The plan of the paper is as follows: Section II discusses the previous research related to the competitive impact of credit unions, and Section III presents the empirical model. Section IV discusses data sources and variable construction, while Section V presents tabular and estimation results. A concluding section summarizes the main findings of the paper and discusses policy implications.

\section{Previous Research}

Despite the growing importance of credit unions as potential competitors of banks, investigations of the competitive interactions between credit unions and banks have been few. Using a 1971 data set consisting of 412 Pennsylvania banks, Hannan (1984) found no

${ }^{5}$ As currently practiced, Federal Reserve analyses employ the Hirschman-Herfindahl index (calculated as the sum of squared deposit shares of banks and thrift institutions in a geographic market) as a screen to determine which proposed mergers and acquisitions merit further examination. Although the deposit shares of credit unions are not included in calculating the index, the merger screen for banking is more relaxed than the screen traditionally used by the Department of Justice for other industries. This more liberal screen is designed to roughly account for competition from nonbanking firms, including credit unions. Also, credit union competition may be used as a mitigating factor in cases where their presence in the market is considerably higher than usual. 
statistically significant relationship between the importance of credit unions in local Pennsylvania markets and the passbook savings rates (as well as hours of operation) of banks operating in those markets. These insignificant findings, however, may be attributable simply to the fact that credit unions in most Pennsylvania local markets did not have a substantial presence in 1971.

Recent evidence of competitive interactions between banks and credit unions has been reported by Emmons and Schmid (1999, 2000a, 2000b). One of their more interesting findings concerns the relationship between banking market concentration and occupational credit union "participation rates," defined as the ratio of the number of members of a credit union to the number of people that legally may become a member if they so choose. They report strong evidence of a positive relationship, consistent with the notion that less attractive bank prices and services in more concentrated banking markets induce potential members of credit unions to become members. They also allow for, and find evidence of, reverse causation, wherein an increase in the rate of participation at credit unions in a given year causes more banking market concentration during the next year, all else equal.

Tokle and Tokle (2000), in a study using deposit rates surveyed in 1998, report a direct examination of the relationship between the deposit rates offered by 122 banks located in Idaho and Montana and the share of market deposits accounted for by credit unions (and, separately, savings and loan associations). Regressing bank deposit rates on the deposit shares of credit unions and other explanatory variables, they find a positive coefficient of credit union share for all three deposit rates surveyed, with statistical significance in the case of one- and two-year CD rates. This study appears to be the first to find a direct procompetitive impact by credit unions on bank deposit rates. It does, however, apply to a rather limited rural sample.

A competitive impact of credit unions on bank consumer loan rates has been reported recently by Robert Feinberg (2001, 2002b). Feinberg's analysis employs as dependent variables the rates charged by banks for unsecured consumer loans and auto loans and uses a panel of banks surveyed quarterly for the $1992-97$ period. He reports a significant negative coefficient of the share of market deposits accounted for by credit unions in regressions explaining new-car loan rates, suggesting a procompetitive impact of credit unions, at least for this type of consumer loan. 
Because of the increasing importance of credit unions as potential competitors of banks and thrift institutions, more detailed examinations of the competitive impact of credit unions are in order. This paper reports a direct examination of the impact of credit unions on retail deposit rate setting by a large number of banks and savings and loans institutions (S\&Ls). In contrast to previous studies, the sample employed covers the nation as a whole, incorporates all large urban areas, and employs survey data on deposit rates for a substantially larger number of institutions than previously employed. In calculating the market share accounted for by credit unions, adjustments are made for credit unions that have offices in more than one defined market. The paper also explicitly examines the distinction between community and occupational credit unions, since they are subject to potentially important differences in the restrictions placed on their memberships. Other innovations, such as use of reported information on the "potential customers" of credit unions and the use of arguably better measures of employee wage rates and office rental rates, are also incorporated in the analysis.

\section{The Empirical Model}

The empirical analysis will consist of multivariate estimations in which variables indicating the observed deposit rates offered by banks are regressed on measures indicating the importance of credit unions in defined geographic markets, controlling for other factors likely to influence bank rate setting behavior.

Virtually all models of imperfect competition imply that increasing entry or an increase in supply emanating from a competitive fringe will result in pricing more favorable to the consumer or purchaser. Feinberg (2001) employs a price-leadership model in which commercial banks and thrifts collectively play the role of price leader and credit unions represent the competitive fringe. In Feinberg (2002a), he reports evidence that this model better explains credit union pricing than does a Cournot model. It implies that the bigger is the competitive fringe represented by credit unions, the more elastic is the net demand or, in the case of bank deposits, the net deposit supply, faced by non-credit unions. Thus, a positive relation between the collective credit union share of the market and bank deposit rates is implied.

This prediction would also result from a spatial model in which, for reasons having to do with convenience or exogenous cost advantages enjoyed by credit unions, credit unions offer 
consumers a more favorable combination of rates and deposit services at any given distance from the depositor's residence to the institution. Since rates in such a model are determined at locations where individuals are indifferent between two competing institutions, the extent to which credit unions operate offices in the relevant market under these circumstances would clearly result in higher deposit rates offered by non-credit unions.

Deferring for a moment the issue of the potential endogeneity of any measure of credit union market share, I estimate equations of the following type:

$$
\begin{gathered}
r_{i j}=\beta_{0}+\beta_{1} c_{j}+\beta_{2} \text { hhi }_{j}+\beta_{3} \text { telwage }_{j}+\beta_{4} \text { rent }_{j}+\beta_{5} \ln \left(\text { mktpop }_{j}\right) \\
\beta_{6} \ln \left(\text { size }_{i}\right)+\beta_{7} \text { thrift }_{i}+\beta_{8} \text { mmbnkshr }_{j},
\end{gathered}
$$

where $r_{\mathrm{ij}}$ represents the deposit rate charged by bank or thrift $i$ in market $j, c u_{j}$ is a measure of the "share" or "importance," collectively, of credit unions operating in market $j, h h i_{j}$ denotes the Hirschman-Herfindahl index of market concentration constructed from bank and thrift market shares, telwage $e_{\mathrm{j}}$ measures the average teller wage in market $\mathrm{j}$, rent $t_{j}$ is an index of the office rental rate in market $j, \ln \left(\right.$ mktpop $\left._{\mathrm{j}}\right)$ is the natural $\log$ of the population of market $j, \ln \left(\operatorname{size}_{\mathrm{i}}\right)$ is the natural $\log$ of the total assets of bank or thrift $i$, thrift $_{\mathrm{i}}$ is a dummy variable receiving a value of one if institution $i$ is a thrift and zero if it is a commercial bank, and $m m b n k s h r_{\mathrm{j}}$ denotes the proportion of deposits in market $j$ accounted for by institutions that operate predominantly in markets other than market $\mathrm{j}$.

The coefficient of the variable of primary interest, $c u_{j}$, is predicted to be positive if credit unions have a procompetitive impact on bank and thrift deposit pricing. The coefficient of $h h i_{j}$ is expected to be negative if, as implied by the standard structure-conduct hypothesis, institutions in more concentrated markets are more likely to engage in some form of noncompetitive behavior. Since both the mean teller wage in the market (telwage $_{\mathrm{j}}$ ) and the office rental rate in the market $\left(r e n t_{j}\right)$ influence positively the cost of operating in the market, they are predicted, if anything, to have a negative impact on deposit rates.

The proportion of deposits in the market accounted for by institutions that operate predominantly in markets other than market $\mathrm{j}\left(m m b n k s h r_{\mathrm{j}}\right)$ is introduced because of previous 
findings that the participation by multimarket banks in a local market induces single-market institutions to offer lower rates, all else equal (Hannan and Prager, 2001). It has been found that multimarket institutions tend to offer the same rates in all the markets in which they operate (Radecki), and that, within the same market, they tend to offer lower deposit rates than singlemarket institutions (Hannan and Prager, 2001). If these lower deposit rates are not more than compensated for with better service (which is unobservable), then lower deposit rates offered by competing banks in the market may result.

Two variables, the population of the market and the asset size of the institution, are entered in log form because they a highly skewed in the positive direction and because it is not plausible that these size measures would have a linear relationship with deposit rates throughout the wide ranges over which the values of these variables are observed. The log of the population of the market $\mathrm{j}, \ln \left(\right.$ mktpop $\left._{j}\right)$, is introduced to control for the numerous and generally unobservable differences that may exist between larger and smaller market areas, with no prediction regarding the sign of its coefficient.

The coefficient of $\ln \left(\right.$ size $\left._{i}\right)$ may be either positive or negative. A positive coefficient would be consistent with the notion that larger institutions are able to provide deposit services more efficiently and thus offer higher deposit rates, while a negative coefficient would be consistent with the notion that, because of the greater range of services offered by larger banks, depositors are willing to accept lower rates for their deposits in exchange for a more attractive bundle of services. A negative coefficient would also be suggested if larger institutions have greater access to cheaper wholesale sources of funds, thus reducing the rates for retail funds that larger institutions find it in their interest to offer.

\section{The Data}

The data on deposit rates offered by individual institutions were obtained from surveys conducted by Bank Rate Monitor in 1998. For each of over 100 different metropolitan areas, the Bank Rate Monitor surveys the five banks and the five thrifts having the largest share of deposits in the metropolitan area. Thus, the sample is not representative of the population of banks and thrifts in the U.S. as a whole. It is, however, more representative of the institutions in which most urban customers maintain deposit accounts. Following most previous research, 
Metropolitan Statistical Areas (MSA) will be assumed to represent the relevant geographic markets in which financial institutions compete for deposit customers. ${ }^{6}$

Clearly, this is not a sample designed to capture the effects of differences in the competitive environment in which banks and thrift institutions operate. The reason is that, compared to other geographic areas typically defined as markets, the largest 100 metropolitan areas are relatively unconcentrated, and the variation in any measure of market concentration will not be pronounced. Further, to the extent that the impact of credit unions on bank and thrift deposit rates depends on the existence of a noncompetitive environment, we are less likely to find evidence of such an effect with this particular sample. By focusing on the largest depository institutions in the largest metropolitan areas, however, the sample does include those markets in which a very large proportion of the nation's depositors reside.

Because the Bank Rate Monitor surveys the largest banks and thrift institutions in the 100 large metropolitan areas, many of the largest multimarket banks are surveyed numerous times, once for each market in which they have a substantial presence. Since the purpose of the analysis is to trace the relationship between the presence of credit unions in an institution's geographic market and the deposit rates that the institution offers its customers, the question of how to treat institutions that operate in more then one geographic market must be addressed.

Biehl (2000), Heitfield (1999), and Radecki (1998) have all reported evidence that large banking organizations located in several different metropolitan areas tend to offer the same deposit rates across metropolitan areas. ${ }^{7} \quad$ This implies that observations of the same bank in different markets cannot be treated as independent of each other. After excluding institutions for which data are missing, and allowing only one observation of each institution, 356 institutions remain in the sample.

Of these institutions, approximately 100 do not have a majority of their deposits in any one market. The pricing behavior of such institutions is probably a function of all the

${ }^{6}$ See, for example, Calem and Carlino (1991) and Hannan (1991).

${ }^{7}$ Heitfield (1999) notes that "single-market" banks do not charge identical rates in these same areas, indicating that this finding of identical rates on the part of "multimarket" banks cannot be taken as evidence of broader geographic markets. Biehl (2000) reaches similar conclusions. 
characteristics (including credit union presence) of the different areas in which they operate. Because of the difficulty in obtaining reliable measures of the importance of credit unions in all the different areas in which such institutions may operate, the approach taken here will be to consider the behavior of only those banks and thrift institutions that operate predominantly in one metropolitan area. This restriction shrinks the sample to approximately 250 banks and thrift institutions surveyed by the Bank Rate Monitor in 1998. Results obtained using a sample that includes institutions that do not operate predominantly in one market yield equivalent results (not reported).

There are several different measures that one can employ as a proxy for the importance of credit unions in local geographic markets. The most obvious is the share of total market deposits (including those of credit unions) accounted for by credit unions-the measure used by both Feinberg (2001) and Tokle and Tokle (2000). Of the different measures to be employed, this measure (to be denoted cudepshare $_{j}$ ) is likely to exhibit the greatest degree of endogeneity, since differences in the deposit rates observed for institutions in the sample are likely to influence the extent to which credit union members hold their deposits in credit unions. The resulting correlation between the deposit share of credit unions and the error term will result in biased and inconsistent coefficient estimates. Because higher deposit rates offered by banks and thrift institutions should, if anything, cause a reduction in the deposit share of credit unions in the market, this form of endogeneity should impart a negative bias to an OLS estimate of the coefficient of cudepshare . $_{\mathrm{j}}$

Also, the deposit share of credit unions probably underestimates the true proportion of retail deposits accounted for by credit unions, since the deposit data for banks and thrift institutions necessarily include substantial amounts of large-denomination "wholesale" and commercial deposits. To the extent that this introduces noise into the measurement of credit unions' true deposit shares, the coefficients of cudepshare $_{j}$ will be biased toward zero.

Fortunately, alternative measures of the importance of credit unions in local markets can be constructed from a number of items included on the Statement of Financial Conditions, submitted by credit unions to the National Credit Union Administration (NCUA). Since each credit union must report the number of its members, an alternative measure to be employed will be the ratio of credit union members in a metropolitan area to the population in the area over 18 
years of age (to be denoted cumempop $_{\mathrm{j}}$ ). Such a measure is likely to involve less endogeneity from reverse causation than a measure of deposit share, since differences in bank and thrift deposit rates would probably influence credit union membership less severely than they would credit union deposit balances. This measure, however, probably overestimates the importance of credit unions in local markets, since many credit union members keep very little in their accounts. An errors-in-variable bias is also possible with the use of this measure, since it too undoubtedly measures the true importance of credit unions with noise.

Another piece of information provided on the Statement of Financial Conditions is the number of potential customers that the credit union estimates that it has. By law, credit unions are restricted to serving individuals that are united by a common bond of occupation or association, or belong to groups within a well-defined neighborhood, community, or rural district, and they are thus required to provide an estimate of the size of this group. For the socalled occupational credit unions, which make up the vast majority of credit unions, this is likely to be the number of employees in the firm that the credit union is associated with and the immediate family members of those employees. For the so-called community credit unions, it could be the general population of the entire local area.

An alternative measure of the importance of credit unions in a local area will be the number of potential members claimed by occupational credit unions operating in the area, divided by the population of the area that is over 18 years old (to be denoted cupmempop s. $_{\mathrm{j}}$. Because community credit unions can (and from the data, apparently do) claim everyone in the local market as a potential member, such a measure would make little sense for community credit unions. Thus, it will be applied only to the vast majority of credit unions classified as occupational credit unions.

An alternative but related measure employed is the proportion of adults in the market that are not claimed as potential members of any of the occupational credit unions in the market. This may be expressed as:

$$
P_{j}=\Pi_{i}\left(1-\text { cupmempop }_{i}\right)
$$

where сиртетрор $_{\mathrm{i}}$ is the ratio of potential members claimed by individual credit union $\mathrm{i}$ to the 
adult population of the metropolitan area $\mathrm{j}$. Because this measure was found to yield coefficients equivalent to the closely related measure, сuретрор $_{\mathrm{j}}$, results obtained using this measure are not reported below.

These measures should be exogenous in estimations of (1), since it is not plausible that differences in the rates offered by banks and thrifts would materially influence the number of potential members of occupational credit unions. They may, however, be very noisy measures of the importance of credit unions to the pricing decisions of banks and thrift institutions, since they exclude community credit unions, may count numerous individuals as potential members that in fact have no interest in credit union membership, and could at any rate represent a fairly inaccurate guess on the part of credit union management.

All of these measures are compromised, to some extent, by the fact that credit unions, particularly the larger ones, may operate offices in more than one local area. Unlike the case of banks and thrift institutions, office-specific information on credit union deposits is not available. Fortunately, directories of credit union offices do exist. The directory produced by Thompsons was employed to apportion credit union activity-- measured, alternatively, by deposits, number of members, and number of potential members--according to office locations under the assumption that all offices are equal with respect to these activities. Alternative weightings in which the headquarter's office is given a substantially greater share of credit union activity than other offices were found to make little difference in observed results.

The Hershmann-Herfindahl index, defined as the sum of the sqaured market shares of institutions in the market, is constructed from the branch shares of banks and thrift institutions in the market. Branches, rather than deposits, are used to construct depository institution shares because branch numbers are less likely to be influenced by deposit rates, making the index less prone to problems associated with endogeneity.

Data on the mean teller wages (telwage $e_{\mathrm{j}}$ ) in each metropolitan area are taken from the 1998 Occupational Employment Survey of the Bureau of Labor Statistics. The index of areaspecific office rental rates was obtained from a study of post office rental rates conducted by Anthony Yezer of George Washington University. ${ }^{8}$ Data on the total population and the

${ }^{8}$ I wish to thank Anthony Yezer for graciously supplying these data. 
population over 18 years of age in each metropolitan area are obtained from data published by the U.S. Bureau of the Census, and data on the asset size of commercial banks and thrift institutions are obtained from bank and thrift call reports.

The proportion of market deposits accounted for by predominantly multimarket institutions $\left(m m b n k s h r_{\mathrm{j}}\right)$ is constructed as the proportion of market deposits accounted for by institutions that have less than half of their deposits in market j. Typically, the multimarket institutions that satisfy this restriction have substantially less than half of their deposits in the observed market. The data employed to calculate this variable are obtained from the FDIC's Summary of Deposits.

\section{The Results}

Before considering the results of estimations of (1), consider first the means of the different measures of the importance of credit unions to be used in the analysis. Table 1 reports the unweighted mean values of these measures for the approximately 80 metropolitan areas employed in the regression analyses. Mean values are also reported for two subcategories of credit unions: occupational and community. Note from the first column of table 1 that credit unions in 1998 made up, on average, about 7.5 percent of the combined deposits of banks, thrifts, and credit unions in these markets, while about 27 percent of the population over 18 years of age in these markets are counted as members of credit unions. This large disparity undoubtedly reflects the fact that many "members" of credit unions keep very small amounts in their credit union accounts. It may also reflect some double counting, to the extent that individuals are members of more than one credit union.

A comparison of the shares of the last two columns in table 1 indicates the overwhelming dominance of occupational credit unions over community credit unions as measured either by deposit shares or by the proportion of the population over 18 years of age that are members. In these urban markets, occupational credit unions account for nearly 90 percent of credit union activity, measured either in terms of deposit shares or the proportion of the adult population that are members.

The final row of table 1 lists the average ratio of "potential members" claimed, collectively, by occupational credit unions in each metropolitan area, divided the area's 
population over 18 years of age. As indicated, about 60 percent, on average, of the entire adult population are claimed to be potential members. This ratio undoubtedly reflects severe double counting, since for a few of the metropolitan areas in the sample, more potential members are claimed collectively than there are people over 18. This ratio is not reported for community credit unions, since every person in the market could be considered a potential member, and, it would appear, community credit unions frequently report accordingly.

Table 2 lists definitions of the various explanatory variables employed in the econometric analysis, while tables 3 through 5 present estimations of (1) for three different deposit accounts: money market deposit accounts (table 3), interest checking (table 4), and three-month certificates of deposit (table 5). In each of these tables, the results of three different regressions are presented, according to whether the importance of credit unions is measured by market deposit share (cudepshare $e_{\mathrm{j}}$ ), by the ratio of total members of credit unions to the adult population in the market $\left(\right.$ cumempop $_{\mathrm{j}}$ ), or by the ratio of total potential members of occupational credit unions to the adult population in the market (cupmempop ). $_{\mathrm{j}}$.

As indicated in table 3 for the case of money market deposit accounts, all three measures of the importance of credit unions in the market have positive signs, consistent with the hypothesis that credit unions have a procompetitive effect on the deposit pricing of banks and thrift institutions, with statistical significance for two of the three measures. The coefficient of the deposit share of credit unions is not statistically significant, while the measure based on credit union membership is significant at the 5 percent level, and that based on the potential membership of occupational credit unions is significant at the 10 percent level.

We have noted that endogeneity stemming from reverse causation, which is likely to be most severe in the case of cudepshare $_{\mathrm{j}}$, would impart a negative bias to the coefficient, and this may be reflected in these results. The coefficient of cumempop $_{\mathrm{j}}$, which is the most significant of the three measures, implies that an increase of one standard deviation in the number of credit union members per adult population in the market would cause the rate offered on money market deposit accounts by banks and thrift institutions to increase about 11 basis points in 1998. With a sample average rate for money market deposit accounts of about 2.68 percent, this comes to an increase of about 4 percent. Equivalent calculations yield an increase of only 4 basis points (or about 1.5 percent) for the other two measures. Thus the measure based on number of credit 
union members appears to be the most significant quantitatively as well as statistically, at least in the case of money market deposit accounts.

The coefficients of other explanatory variables are also of interest. The coefficients of market concentration $\left(h h i_{\mathrm{j}}\right)$ are negative, as commonly predicted if noncompetitive behavior is more likely in more concentrated markets. Levels of significance, however, do not reach the 10 percent level. This may reflect the fact that almost none of the approximately 80 large urban areas that make up the sample are highly concentrated. The average value of this measure for the sample is 867 , with the most concentrated market yielding a value of only 2,438 , barely in the range traditionally considered to be concentrated.

Of the two measures designed to capture the cost of operation in the market (those measuring teller wages and office rent), only the coefficients of the index of office rent has the predicted negative sign, and it is not significant. The coefficients of market size, as measured by the natural log of the market's population, are positive but significant in only one case.

The most significant coefficients in these regressions are those of the observed institution's size, measured by the natural $\log$ of the institution's assets, $\ln \left(\operatorname{siz}_{\mathrm{j}}\right)$. Coefficients are negative and significant at the 1 percent level, indicating that, all else equal, larger institutions offer lower rates.

Coefficients of thrift $t_{\mathrm{j}}$ are positive, suggesting that thrift institutions offer higher rates on money market deposit accounts than do banks, but these coefficients are significant in only one case. Finally, the negative coefficients of $m m b n k s h r_{\mathrm{j}}$ are consistent with the prediction (and found by Hannan and Prager [2002] using a larger data set) that the proportion of deposits accounted for by institutions not predominantly in the market has a negative effect on the deposit rates of those institutions that are, but again, significance is observed in only one case.

Table 4 presents results for equivalent regressions in which the rate offered on interest checking serves as the dependent variable. As indicated, all three measures of the market presence of credit unions have positive coefficients, but only the measure based on the number of credit union members in the market is significant. Its magnitude suggests that an increase of one standard deviation in the number of credit union members per adult population in the market would cause an 11 basis point increase in the rates offered on interest checking accounts by banks and thrifts in the market. With a sample average of about 1.6 percent offered for interest 
checking, this amounts to an increase of about 7 percent. Equivalent calculations for the other two measures of the importance of credit unions in the market yield only a four basis-point increase, or 2.5 percent. Other aspects of the regression results are not markedly different than those reported for money market deposit accounts in table 3, except that reported $\mathrm{R}^{2} \mathrm{~s}$ are substantially higher, the coefficients of both measures of input prices (telwage $e_{\mathrm{j}}$ and rent $_{\mathrm{j}}$ ) have the predicted negative signs (but remain insignificant), and the coefficients of $m m b n k s h r_{\mathrm{j}}$ are significant in two of the three reported regressions.

Finally, table 5 presents the results of equivalent regressions in which the rate offered on three-month certificates of deposit is employed as the dependent variable. Again, the coefficients of all three measures of the market presence of credit unions have the predicted positive signs, but in these regressions, the coefficients of measures based on deposit share and members in the market are significant, while the coefficient of the measure based on potential members is not. Coefficient magnitudes suggest that an increase of one standard deviation would cause a 10 basis point increase in the rate offered on three-month certificates of deposit in the case of cudepshare $_{\mathrm{j}}$, a 9 basis point increase in the case of cumempop $_{\mathrm{j}}$, and a 6 basis point increase in the case of cupmempop $_{\mathrm{j}}$. With a sample average of about 4.3 percent offered for three-month certificates of deposits, these increases amount to about 2.3 percent, 2.1percent, and 1.4 percent, respectively, of the sample average.

The coefficients of the other explanatory variables in the analysis are equivalent to those reported in tables 3 and 4, except that the coefficient of rent $t_{\mathrm{j}}$ is negative, as predicted, and highly significant in all three regressions, and the coefficients of thrift $\mathrm{i}_{\mathrm{i}}$ is positive and significant in all three regressions, indicating that, all else equal, thrift institutions offer higher CD rates than do banks. The coefficients of market population are also positive and significant in all three regressions, indicating that, all else equal, three-month $\mathrm{CD}$ rates tend to be higher in larger metropolitan areas.

\section{Conclusion}

In large urban areas, credit unions accounted for about 7.5 percent of deposits in 1998 , and the ratio of credit union members to adult population averaged about .27. Even allowing for double counting, it is clear that credit union members account for a substantial part of the adult 
population in these areas. Because of the increasing significance of credit unions as potential competitors for consumer deposits, this paper examines the impact of the market presence of credit unions, variously measured, on the rates for three different types of consumer deposits offered by banks and thrift institutions. These are money market deposit accounts, interest checking accounts, and three-month certificates of deposit. Focusing on about 80 different large metropolitan areas, three different measures of the importance of credit unions in each area are constructed. One is the deposit share of credit unions in the "market," another measures the number of credit union members per adult population, while a third measures the number of selfreported "potential members" of occupational credit unions per adult population of the area. In calculating each of these measures, adjustments are made to account for those cases in which a credit union operates offices that are outside the defined market.

Regression analyses designed to explain differences in the deposit rates offered by banks and thrift institutions yield positive coefficients of these measures, with statistical significance in a number of cases. The number of credit union members per adult population in the market exhibits the most explanatory power of the three measures, at least in the case of money market deposit accounts and interest checking. Coefficient magnitudes are such that an increase of one standard deviation in this measure would result in an increase of 11 basis points in the rates offered for these two types of accounts, representing a 4 percent increase relative to the sample average in the case of money market deposit accounts and a 7 percent increase in the case of interest checking accounts. Problems associated with reverse causation, errors in measurement, and a sample that does not include highly concentrated markets are noted as aspects of the study that are likely to result in an underestimate of the true competitive impact of credit unions.

Credit unions are growing in importance, and because of the finding that the presence of credit unions exhibits in a number of cases a significant positive relationship with bank and thrift deposit rates (despite circumstances that militate against such a finding), it is clear that they represent a competitive force in urban banking markets that, more and more, will have to be taken into account by banks and thrift institutions in those markets, and by regulators responsible for keeping markets competitive. 


\section{References}

American Bankers Association. The Credit Union Industry: Trends, Structure, and Competitiveness Washington, D.C. 1989.

Biehl, Andrew. "The Extent of the Market for Retail Banking Deposits," (December 2000) unpublished manuscript.

Calem, Paul, and Gerald Carlino. "The Concentration/Conduct Relationship in Bank Deposit Markets," Review of Economics and Statistics 73 (1991) pp. 268-273.

Emmons, William R., and Frank A Schmid. "Credit Unions and the Common Bond," Review of the Federal Reserve Bank of St. Louis, (September/October 1999), pp. 41-63.

. "Banks, Credit Unions, and the Dynamics of Competition," Federal Reserve Bank of St. Louis working paper 2000-006a, 2000. "Bank Competition and Concentration: Do Credit Unions Matter?" Review of the Federal Reserve Bank of St. Louis (May/June 2000), pp. 29-42.

Feinberg, Robert M., "The Competitive Role of Credit Unions in Small Local Financial Services Markets," Review of Economics and Statistics, (August 2001).

"Credit Unions: Fringe Suppliers or Cournot Competitors?" Review of Industrial Organization 20 (March 2002a) pp. 105-113.

. "The Determinants of Bank Rate-Setting in Local Consumer Lending Markets: 
Comparing Market and Institution-Level Results," Working Paper, 2002 b.

Hannan, Timothy H. "Competition between Commercial Banks and Thrift Institutions: An empirical Examination,” Journal of Bank Research, 15, pp. 8-14.

. "Bank Commercial Loan Markets and the Role of Market Structure:

Evidence from Surveys of Commercial Lending," Journal of Banking and Finance, (February 1991) pp. 133-149.

and Robin A. Prager. "The Competitive Implications of Multimarket Bank Branching,” Working Paper 2001-43, Federal Reserve Board, 2001.

Heitfield, Erik A. "What do Interest Rate Data Say About the Geography of Retail Banking Markets?" The Antitrust Bulletin (Summer 1999) pp. 333-347.

Radecki, Lawrence J. “The Expanding Geographic Reach of Retail Banking Markets,” Federal Reserve Bank of New York Economic Policy Review (June 1998) pp. 15-33.

Tokle, Robert J., and Joanne G. Tokle. "The Influence of Credit Union and Savings and Loan Competition on Bank Deposit Rates in Idaho and Montana," Review of Industrial Organization 17 (2000), pp. 427-438.

U.S. Treasury Department. Credit Unions, U.S. Government Printing Office, 1997. 


\section{Table 1}

The Means of Various Measures Credit Union Presence in a Sample of Large Metropolitan Markets, 1998

\begin{tabular}{l|c|c|c}
\hline & All Credit Unions & $\begin{array}{c}\text { Occupational Credit } \\
\text { Unions }\end{array}$ & $\begin{array}{c}\text { Community Credit } \\
\text { Unions }\end{array}$ \\
\cline { 2 - 4 } $\begin{array}{l}\text { Share of deposits } \\
\text { (decimals) }\end{array}$ & .075 & .068 & .008 \\
$\begin{array}{l}\text { Ratio of members to } \\
\text { the pop. }>18 \text { yrs. }\end{array}$ & .267 & .240 & .032 \\
$\begin{array}{l}\text { Ratio of "potential" } \\
\text { members" of occ. } \\
\text { credit unions to the } \\
\text { pop. }>18 \text { yrs. }\end{array}$ & & .61 & \\
\hline
\end{tabular}


Table 2

Variable Definitions

\begin{tabular}{|c|c|}
\hline cudepshare $_{j}$ & $\begin{array}{l}\text { Estimated credit union deposits in market } \mathrm{j} \text {, divided by the sum of } \\
\text { bank deposits, thrift deposits, and estimated credit union deposits in } \\
\text { market } \mathrm{j} \text {. }\end{array}$ \\
\hline cumempop $_{\mathrm{j}}$ & $\begin{array}{l}\text { Estimated number of members of credit union members in market } \mathrm{j} \text {, } \\
\text { divided by the population over } 18 \text { years of age in market } \mathrm{j} \text {. }\end{array}$ \\
\hline cupmempop $_{\mathrm{j}}$ & $\begin{array}{l}\text { Estimated number of potential members of occupational credit } \\
\text { unions in market } \mathrm{j} \text {, divided ty the population over } 18 \text { years of age in } \\
\text { market } \mathrm{j} \text {. }\end{array}$ \\
\hline hhi $_{j}$ & $\begin{array}{l}\text { The Hirschman-Herfindahl index of concentration, calculated as the } \\
\text { sum of the squared branch shares of banks and thrift institutions in } \\
\text { market } j \text {. }\end{array}$ \\
\hline telwage $_{\mathrm{j}}$ & The mean teller wage in market $\mathrm{j}$. \\
\hline rent $_{\mathrm{j}}$ & An index of the office rent in market $j$. \\
\hline $\ln \left(\right.$ mktpop $\left._{\mathrm{j}}\right)$ & Natural log of the population of market $\mathrm{j}$. \\
\hline $\ln ($ bksize $)$ & Natural log of the assets of institution i. \\
\hline thrift $_{j}$ & $\begin{array}{l}\text { A dummy variable receiving the value of one if institution i is a thrift } \\
\text { institution, and zero otherwise. }\end{array}$ \\
\hline mmbnkshr $_{j}$ & $\begin{array}{l}\text { The proportion of deposits in market } \mathrm{j} \text { that are accounted for by } \\
\text { institutions that have less than half of their deposits in market; }\end{array}$ \\
\hline
\end{tabular}


Table 3

The Rates Offered by Banks and Thrift Institutions on Money Market Deposit Accounts and Measures of the Importance of Credit Unions in Metropolitan Markets

\begin{tabular}{|c|c|c|c|}
\hline & (1) & (2) & (3) \\
\hline Intercept & $\begin{array}{c}3.55 \\
(3.94)\end{array}$ & $\begin{array}{c}2.58 \\
(2.53)\end{array}$ & $\begin{array}{c}3.05 \\
(3.24)\end{array}$ \\
\hline cudepshare $_{j}$ & $\begin{array}{c}.92 \\
(.98)\end{array}$ & & \\
\hline cumempop $_{j}$ & & $\begin{array}{r}.88^{*} \\
(2.22)\end{array}$ & \\
\hline cupmempop $_{\mathrm{j}}$ & & & $\begin{array}{r}.13^{+} \\
(1.78)\end{array}$ \\
\hline hhi $_{\mathrm{j}}$ & $\begin{array}{l}-2.36 \\
(-1.52)\end{array}$ & $\begin{array}{l}-2.39 \\
(-1.56)\end{array}$ & $\begin{array}{c}-.85 \\
(-.53)\end{array}$ \\
\hline telwage $_{\mathrm{j}}$ & $\begin{array}{c}.07 \\
(.93)\end{array}$ & $\begin{array}{c}.07 \\
(1.03)\end{array}$ & $\begin{array}{c}.08 \\
(1.10)\end{array}$ \\
\hline rent $_{j}$ & $\begin{array}{c}-.05 \\
(-.71)\end{array}$ & $\begin{array}{c}-.06 \\
(-.71)\end{array}$ & $\begin{array}{c}-.04 \\
(-.49)\end{array}$ \\
\hline $\ln \left(\mathrm{mktpop}_{\mathrm{j}}\right)$ & $\begin{array}{c}.07 \\
(1.00)\end{array}$ & $\begin{array}{r}.13^{+} \\
(1.71)\end{array}$ & $\begin{array}{c}.08 \\
(1.15)\end{array}$ \\
\hline $\ln \left(\right.$ bksize $\left._{\mathrm{i}}\right)$ & $\begin{array}{c}-.15^{* *} \\
(-4.92)\end{array}$ & $\begin{array}{c}-.15^{* * *} \\
(-5.09)\end{array}$ & $\begin{array}{c}-.14^{* * *} \\
(-4.86)\end{array}$ \\
\hline thrift $_{\mathrm{i}}$ & $\begin{array}{c}.11 \\
(1.35)\end{array}$ & $\begin{array}{c}.12 \\
(1.41)\end{array}$ & $\begin{array}{r}.16^{+} \\
(1.87)\end{array}$ \\
\hline $\mathrm{mmbnkshr}_{\mathrm{j}}$ & $\begin{array}{c}-.24 \\
(-1.15)\end{array}$ & $\begin{array}{c}-.31 \\
(-1.52)\end{array}$ & $\begin{array}{r}-.37^{+} \\
(-1.71)\end{array}$ \\
\hline $\begin{array}{l}\mathrm{N} \\
\mathrm{R}^{2}\end{array}$ & $\begin{array}{l}245 \\
.147\end{array}$ & $\begin{array}{l}245 \\
.160\end{array}$ & $\begin{array}{r}237 \\
.157\end{array}$ \\
\hline
\end{tabular}

Note: $\quad$ t-statistics in parentheses. The symbols $+{ }^{*}$, and ** denote significance at the 10,5 , and 1 percent levels, respectively. 
Table 4

The Rates Offered by Banks and Thrift Institutions on Interest Checking and the Importance of Credit Unions in Metropolitan Markets

\begin{tabular}{|c|c|c|c|}
\hline & (1) & (2) & (3) \\
\hline Intercept & $\begin{array}{c}4.85 \\
(5.96)\end{array}$ & $\begin{array}{c}3.96 \\
(4.28)\end{array}$ & $\begin{array}{c}5.19 \\
(5.96)\end{array}$ \\
\hline cudepshare $_{j}$ & $\begin{array}{c}1.09 \\
(1.27)\end{array}$ & & \\
\hline cumempop $_{\mathrm{j}}$ & & $\begin{array}{r}.84 * \\
(2.31)\end{array}$ & \\
\hline cupmempop $_{\mathrm{j}}$ & & & $\begin{array}{c}.13 \\
(1.06)\end{array}$ \\
\hline hhi $_{\mathrm{j}}$ & $\begin{array}{c}-2.13 \\
(-1.58)\end{array}$ & $\begin{array}{c}-2.13 \\
(-1.60)\end{array}$ & $\begin{array}{l}-1.36 \\
(-.92)\end{array}$ \\
\hline telwage $_{\mathrm{j}}$ & $\begin{array}{c}-.06 \\
(-.86)\end{array}$ & $\begin{array}{c}-.05 \\
(-.74)\end{array}$ & $\begin{array}{c}-.07 \\
(-1.05)\end{array}$ \\
\hline rent $_{j}$ & $\begin{array}{l}-.05 \\
(-.71)\end{array}$ & $\begin{array}{c}-.05 \\
(-.69)\end{array}$ & $\begin{array}{c}-.04 \\
(-.05)\end{array}$ \\
\hline $\ln \left(\right.$ mktpop $\left._{j}\right)$ & $\begin{array}{c}.002 \\
(.03)\end{array}$ & $\begin{array}{c}.06 \\
(.80)\end{array}$ & $\begin{array}{c}-.07 \\
(-.26)\end{array}$ \\
\hline $\ln \left(\right.$ bksize $\left._{\mathrm{i}}\right)$ & $\begin{array}{c}-.17^{* *} \\
(-6.31)\end{array}$ & $\begin{array}{c}-.17^{* *} \\
(-6.51)\end{array}$ & $\begin{array}{c}-.17^{* *} \\
(-6.26)\end{array}$ \\
\hline thrift $_{i}$ & $\begin{array}{c}.08 \\
(1.05)\end{array}$ & $\begin{array}{c}.08 \\
(1.09)\end{array}$ & $\begin{array}{c}.12 \\
(1.48)\end{array}$ \\
\hline mmbnkshr $_{j}$ & $\begin{array}{c}-.27 \\
(-1.44)\end{array}$ & $\begin{array}{r}-.33^{+} \\
(-1.75)\end{array}$ & $\begin{array}{c}-.46^{*} \\
(-2.28)\end{array}$ \\
\hline $\begin{array}{l}\mathrm{N} \\
\mathrm{R}^{2}\end{array}$ & $\begin{array}{c}245 \\
.241 \\
\end{array}$ & $\begin{array}{l}245 \\
.252 \\
\end{array}$ & $\begin{array}{r}236 \\
.250 \\
\end{array}$ \\
\hline
\end{tabular}

Note: t-statistics in parentheses. The symbols,$+{ }^{*}$, and $* *$ denote significance at the 10,5 , and 1 percent levels, respectively. 
Table 5

The Rates Offered by Banks and Thrift Institutions on Three-Month CDs and the Importance of Credit Unions in Metropolitan Markets

\begin{tabular}{|c|c|c|c|}
\hline & (1) & (2) & (3) \\
\hline Intercept & $\begin{array}{c}4.81 \\
(5.43)\end{array}$ & $\begin{array}{c}4.43 \\
(4.33)\end{array}$ & $\begin{array}{c}4.40 \\
(4.63)\end{array}$ \\
\hline cudepshare $_{\mathrm{j}}$ & $\begin{array}{c}2.11^{*} \\
(2.28)\end{array}$ & & \\
\hline cumempop $_{\mathrm{j}}$ & & $\begin{array}{r}.67 * \\
(1.69)\end{array}$ & \\
\hline cupmempop $_{\mathrm{j}}$ & & & $\begin{array}{c}.19 \\
(1.53)\end{array}$ \\
\hline $\mathrm{hhi}_{\mathrm{j}}$ & $\begin{array}{c}-1.97 \\
(-1.36)\end{array}$ & $\begin{array}{c}-1.89 \\
(-1.30)\end{array}$ & $\begin{array}{l}-1.13 \\
(-.70)\end{array}$ \\
\hline telwage $_{\mathrm{j}}$ & $\begin{array}{c}-.09 \\
(-1.24)\end{array}$ & $\begin{array}{c}-.08 \\
(-1.16)\end{array}$ & $\begin{array}{c}-.06 \\
(-.83)\end{array}$ \\
\hline rent $_{\mathrm{j}}$ & $\begin{array}{c}-.19^{*} \\
(-2.43)\end{array}$ & $\begin{array}{c}-.18^{*} \\
(-2.31)\end{array}$ & $\begin{array}{c}-.17^{*} \\
(-2.19)\end{array}$ \\
\hline $\ln \left(\right.$ mktpop $\left._{\mathrm{j}}\right)$ & $\begin{array}{r}.13^{+} \\
(1.86)\end{array}$ & $\begin{array}{c}.15^{*} \\
(1.99)\end{array}$ & $\begin{array}{r}.13^{+} \\
(1.85)\end{array}$ \\
\hline $\ln \left(\right.$ bksize $\left._{\mathrm{i}}\right)$ & $\begin{array}{c}-.07^{*} \\
(-2.29)\end{array}$ & $\begin{array}{c}-.07^{*} \\
(-2.44)\end{array}$ & $\begin{array}{c}-.07^{*} \\
(-2.33)\end{array}$ \\
\hline thrift $_{\mathrm{i}}$ & $\begin{array}{c}.17^{*} \\
(2.08)\end{array}$ & $\begin{array}{c}.17^{*} \\
(1.98)\end{array}$ & $\begin{array}{c}.17^{*} \\
(2.00)\end{array}$ \\
\hline mmbnkshr $_{j}$ & $\begin{array}{l}-.08 \\
(-.41)\end{array}$ & $\begin{array}{c}-.06 \\
(-.27)\end{array}$ & $\begin{array}{c}.05 \\
(.24)\end{array}$ \\
\hline $\begin{array}{l}\mathrm{N} \\
\mathrm{R}^{2}\end{array}$ & $\begin{array}{l}236 \\
.127\end{array}$ & $\begin{array}{r}236 \\
.118 \\
\end{array}$ & $\begin{array}{l}228 \\
.114 \\
\end{array}$ \\
\hline
\end{tabular}

Note: t-statistics in parentheses. The symbols,$+{ }^{*}$, and $* *$ denote significance at the 10,5 , and 1 percent levels, respectively. 
